\title{
Novel Mutation in the ATP-Binding Cassette Transporter A3 (ABCA3) Encoding Gene Causes Respiratory Distress Syndrome in A Term Newborn in Southwest Iran
}

\author{
Farideh Rezaei, ${ }^{1}$ Mohammad Shafiei, ${ }^{1}$ Gholamreza Shariati, ${ }^{2,3}$ Ali Dehdashtian, ${ }^{3}$ Maryam \\ Mohebbi, ${ }^{2,3, *}$ and Hamid Galehdari ${ }^{1}$ \\ ${ }^{1}$ Deptartment of Genetics, Faculty of Science, Shahid Chamran University, Ahvaz, IR Iran \\ ${ }_{3}^{2}$ Narges Medical Genetic Laboratory, Ahvaz, IR Iran \\ ${ }^{3}$ Jundishapur University of Medical Sciences, Ahvaz, IR Iran \\ *Corresponding author: Maryam Mohebbi, Jundishapur University of Medical Sciences, Ahvaz, IR Iran. Tel:+98-9126433468, E-mail: drmaryam.mohebbi1978@yahoo.com
}

Received 2015 May 25; Revised 2015 November 1; Accepted 2015 November 14.

\begin{abstract}
Introduction: $\mathrm{ABCA}$ glycoprotein belongs to the ATP-binding cassette $(\mathrm{ABC})$ superfamily of transporters, which utilize the energy derived from hydrolysis of ATP for the translocation of a wide variety of substrates across the plasma membrane. Mutations in the ABCA3 gene are knowingly causative for fatal surfactant deficiency, particularly respiratory distress syndrome (RDS) in term babies.

Case Presentation: In this study, Sanger sequencing of the whole ABCA3 gene(NCBI NM_001089) was performed in a neonatal boy with severe RDS. A homozygous mutation has been identified in the patient. Parents were heterozygous for the same missense mutation GGA $>$ AGA at position 202 in exon 6 of the ABCA3 gene (c.604G > A; p.G202R). Furthermore, 70 normal individuals have been analyzed for the mentioned change with negative results.

Conclusions: Regarding Human Genome Mutation Database (HGMD) and other literature recherche, the detected change is a novel mutation and has not been reported before. Bioinformatics mutation predicting tools prefer it as pathogenic.
\end{abstract}

Keywords: Surfactant, ABCA3 Gene Mutation, Respiratory Distress Syndrome (RDS), Southwest Iran

\section{Introduction}

ABCA3 glycoprotein belongs to the ATP-binding cassette (ABC) superfamily of transporters which can be found in all organisms from smallest prokaryotes to human. These proteins utilize the energy derived from hydrolysis of ATP for the translocation of a wide variety of substrates across the plasma membrane, and also across intracellular membranes against a concentration gradient $(1,2)$. The superfamily is classified in seven distinct subfamilies of transporters ABCA to ABCG, which in turn is divided in multiple subgroups $(3,4)$.

One of these subfamilies is encoded by the ABCA3 gene located on the short arm of the chromosome 16 (16p13.3) that approximately extends to $80 \mathrm{kbp}$ of the genomic DNA, and consists of 32 exons encoding a polypeptide chain of 1704 amino acids (5). The cDNA of the ABCA3 gene was originally isolated from human modularly thyroid carcinoma cell line in 1996 (6).

$\mathrm{ABCA} 3$ protein has been detected in the limiting membrane of lamellar bodies, organelles for assembly, storage and secretion of pulmonary surfactant in alveolar type II cells. It is considered that $\mathrm{ABCA} 3$ protein translocates lipids into lamellar bodies (7). The ABCA3 protein also is necessary for the correct formation of functionally lamellar bodies, surfactant homeostasis and exact function of lungs (1).

The surfactant consists of two parts: lipids (90\%) and proteins (10\%) (8). Surfactant lipids consist of approximately $70 \%$ phosphatidylcholine particularly as dipalmitoylphosphatidyl-choline, phosphatidylglycerol (10\%), and other lipids at lower levels including phosphatidylethanolamine, phosphatidylinositol etc. (9).

The lipid-rich monolayer structure of pulmonary surfactant is special in that it coats the lumen of alveoli and greatly decreases superficial tension of the alveolar air-liquid interface thus providing mechanical stability and keeping alveolae from atelectasis and collapse at low lung volume (7).

In this study we report a novel mutation that has been discovered in whole exon sequencing of the $\mathrm{ABCA} 3$ gene in a family with respiratory distress syndrome in southwest Iran. 
Rezaei F et al.

\section{Case Presentation}

The index patient was a $2.8 \mathrm{~kg}$ full-term male infant born after an uncomplicated pregnancy at 38 weeks gestational age, via a vaginal delivery, to healthy and consanguineous parents (first cousin couple). His symptoms demonstrated atelectasis, abnormal lung findings and strenuous respiration. There was no family history of lung disease, abortion, mental retardation. He developed severe respiratory distress syndrome.

The patient was urgently hospitalized, ventilation and other routine cares were applied, but unfortunately he was resistant to treatments and died in early days of life.

\subsection{Genetic Analysis}

Genomic DNA was prepared from blood leukocytes (10 $\mathrm{mL}$ ) of the proband, his parents and 70 matched unrelated controls (from related ethnicity) without any respiratory distress syndrome by routine salting out protocol.

The 30 coding regions (exons 3 - 32) of the $A B C A 3$ gene (NCBI NM_001089) and the intron-exon boundaries were amplified by PCR with designed primer pairs using Primer3 software (Table 1) (http://primer3.ut.ee/).

Polymerase chain reaction contained: $100 \mathrm{ng}$ genomic DNA, $12.5 \mu \mathrm{L}$ Master Mix (Amplicon Co.), 25 pmol of each primer and the total of PCR volume was $25 \mu \mathrm{L}$. the PCR was done in 35 cycles: $93^{\circ} \mathrm{C}$ for 1 minute, $63^{\circ} \mathrm{C}$ for $30 \mathrm{~s}$ and $72^{\circ} \mathrm{C}$ for $30 \mathrm{~s}$ and finally the productions of PCR put in the temperature $72^{\circ} \mathrm{C}$ for 5 minutes to complete extension. PCR products were subsequently sequenced using same primers as mentioned in Table 1 and Big Dye Terminator Cycle Sequencing Ready Reaction Kit (Applied Biosystems 3500 DNA Analyzer). Finally, chromatograms were read and analyzed with by Chromas and DNA Baser v4 software.

Table 1. Primers Used for the Amplification of the ABCA3 Gene

\begin{tabular}{lc}
\hline Primer & Sequence \\
\hline abca3-E3-F & CTCTGCGTGTTTCTATTGCG \\
\hline abca3-E3-R & AGACAGCCCTTCCCTCAAG \\
\hline abca3-E4-F & CTTGAGGGAAGGGCTGTCT \\
\hline abca3-E4-R & CGTGGAGGCACCACTAGG \\
\hline abca3-E5-F & CCTGAACCACGCAGATTTTT \\
\hline abca3-E5-R & CTGATGGGCTGTGACTGCT \\
\hline abca3-E6-F & CCTCTGTCTGGATCTCTCGG \\
\hline abca3-E6-R & TGTCACTAGTCAACAGCCCG \\
\hline abca3-E7-F & CAAGCATCTCTTCCCCCAT \\
\hline abca3-E7-R & GCGGTTTCTAGAGTGTTGGG \\
\hline abca3-E8-F & GGACAGTCGGACTCAGGC \\
\hline abca3-E8-R & CTCTCCCCGTCCTCACCA \\
\hline abca3-E9-F & AGTCCTCCTGGTCCACCTCT \\
\hline abca3-E9-R & CAGCCTCTGGGTTATTTCCA \\
\hline abca3-E10-F & CCCTTTTGAGGGCACTGAC \\
\hline
\end{tabular}

\begin{tabular}{|c|c|}
\hline abca3-E10-R & TGATTCGGAAAGAACAGGCT \\
\hline abca3-E11-F & ACACGTGTGCCATCAGGG \\
\hline abca3-E11-R & ACCTCTGCACTCAGAGAGGC \\
\hline abca3-E12-F & GTTGCTTTGCTCGTCACAAA \\
\hline abca3-E12-R & ACTGCCGTGCTGGTAAGTCT \\
\hline abca3-E13-F & GAGCAGGAGAGGCCTTGG \\
\hline abca3-E13-R & TGAGATGGTGTTAAAGGGGG \\
\hline abca3-E14-F & GGATCTTCATGCTGAATGTGG \\
\hline abca3-E14-R & CTCGAGCACATCAGTGGAAA \\
\hline abca3-E15-F & TTCCTCTCACCAGAACCTCG \\
\hline abca3-E15-R & GTCGAGCAGGAGGGGAAC \\
\hline abca3-E16-F & GTGTGGCTCTACCAGCGTC \\
\hline abca3-E16-R & AAGGTAGCAGCCATTCCCTC \\
\hline abca3-E17-F & GGGATCAGCCAAAGATCTCA \\
\hline abca3-E17-R & GGGATCCCATCTTGGATGTA \\
\hline abca3-E18-F & GGGGGTGATGCTTTAGGAAC \\
\hline abca3-E18-R & GAGCCCAGTCCTAGGTGGA \\
\hline abca3-E19-F & ACCATAGTCССТСССТССАС \\
\hline abca3-E19-R & GGGCTTACATGAGGCGTTT \\
\hline abca3-E20-F & CGTCACACAGAACAGCACCT \\
\hline abca3-E20-R & CCTCCСTCAGTACATTCGGA \\
\hline abca3-E21-F & TGATTAGCCATGCTCAGGTG \\
\hline abca3-E21-R & GTCAGTCCTGGGGGCTCT \\
\hline abca3-E22-F & ATAACCGAGAACCCGACCTC \\
\hline abca3-E22-R & GTCTGCAGGGGAACGGAT \\
\hline abca3-E23-F & GTGAGCTCCTCTCAGCTTGG \\
\hline abca3-E23-R & CTGGTGCCTCCCTGTCTG \\
\hline abca3-E24-F & GTCCTGGAGGTGGGTGTG \\
\hline abca3-E24-R & GCAGTGACCACGTCCTGAG \\
\hline abca3-E25-F & GAACCTGGAAGGGGAGGAG \\
\hline abca3-E25-R & AGAGACGTGGGGAGCATCT \\
\hline abca3-E26-F & CCAGACCTCCCACATCCAC \\
\hline abca3-E26-R & GTAGTCAGCTGGCAGGAAGG \\
\hline abca3-E27-F & GAGGCTCAGACTGCTCTGCT \\
\hline abca3-E27-R & СCTGTCTCACCCCTTCAGAG \\
\hline abca3-E28-F & GTGGTCCTCTGGAGGAAGG \\
\hline abca3-E28-R & TGCTATGGGGACCTTGATTC \\
\hline abca3-E29-F & ACTCTCAGCCTTATTCCCCC \\
\hline abca3-E29-R & ACCAGATGCTGATGGGTCTC \\
\hline abca3-E30-F & CTTCCTGTCTGCACAAGCCT \\
\hline abca3-E30-R & GGAGAGGCCTAGGTAGGGG \\
\hline abca3-E31-F & CAAGTCCСАТСТССССААТ \\
\hline abca3-E31-R & TCACCACAGAGGGAGAGACC \\
\hline abca3-E32-F & CTATTGCCAGAGGACTCCCA \\
\hline abca3-E32-R & GATCTGCATGGTCCATTCCT \\
\hline
\end{tabular}




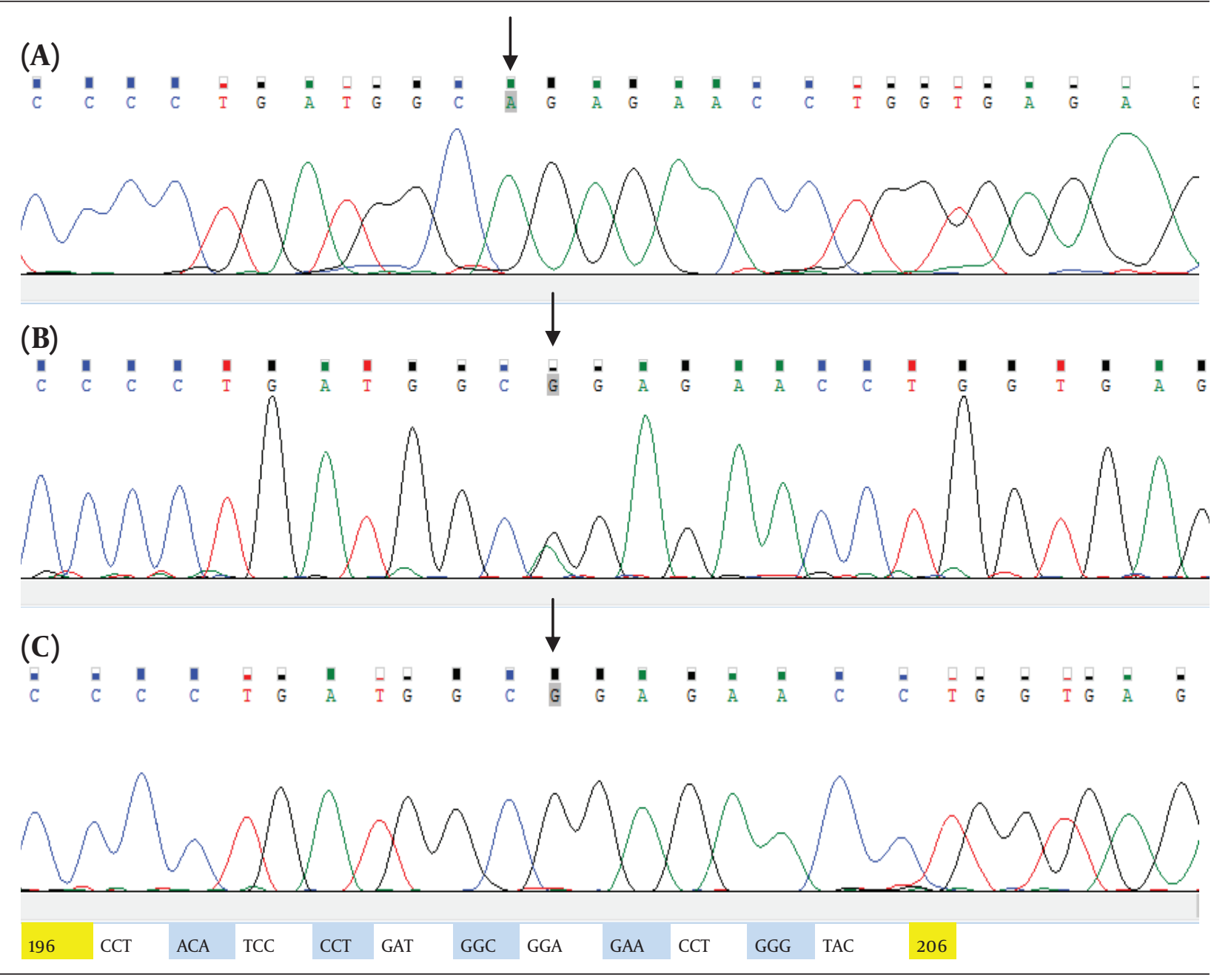

A, Sequencing results show a homozygous GGA > AGA missense in the case of patient; B, a heterozygous GGA > AGA change in his parents; C, control healthy samples were entirely homozygous for wild type allele.

Sequence analysis of entire coding exons and the flanking intronic regions of the $\mathrm{ABCA} 3$ gene from affected infant revealed a homozygous missense mutation GGA $\rightarrow$ AGA substitution at exon 6 , which causes an amino acid exchange of glycine to argenine at codon 202 (p.Gly202Arg/G202R). In this way, his healthy parents were heterozygous for the same missense mutation, while sequence analysis of exon 6 of healthy control Individuals demonstrated no change at this position (Figure 1).

\section{Discussion}

ABCA3 is a member of ABCA subfamily that has a role in transport of lipids and it is most likely that $A B C A 3$ has same work. The ABCA3 gene is larger than other proteins genes involved in surfactant. Nevertheless, it is reasonable that more mutations event in ABCA3 gene, also because the maximum amount of pulmonary surfactant consists of lipids which in turn are transported by ABCA3 proteins. In this view, $\mathrm{ABCA} 3$ gene mutations appear to be the most essential cause of surfactant metabolism and respiratory diseases in newborns.

RDS is a multi-factorial disease with a variety range of clinical symptoms, often occurs in preterm infants and $\mathrm{ABCA} 3$ gene mutations are considered as an important factor causing heredity RDS. Otherwise, neonatal RDS is major cause of morbidity for prematurely born infants. Some of ABCA3 gene mutations cause fatal respiratory distress syndrome of newborns while others of moderate mutations result in chronic interstitial lung disease. The most reported types of mutations with clinical significance are missense, deletions, splicing and insertion mutations (Table 2).

Interestingly, the risk of affected RDS is much more in male than in female neonates. To date, there is no rapid and true test for detecting $A B C A 3$ deficiency; indeed some of children with $\mathrm{ABCA} 3$ mutations have undergone lung transplantation for their respiratory failure. Other treatment options for mild cases are ventilation, oxygenation and surfactant replacement. 
Table 2. Types of Currently Reported ABCA3 Gene Mutations (http://www.hgmd.cf.ac.uk/)

\begin{tabular}{lc}
\hline Mutation Type & Number of Mutations \\
\hline Missense/nonsense & 56 \\
\hline Splicing & 8 \\
\hline Regulatory & 0 \\
\hline Small deletions & 12 \\
\hline Small insertions & 5 \\
\hline Small indels & 1 \\
\hline Gross deletions & 0 \\
Gross insertions/duplica- & 0 \\
tions & \\
Complex rearrangements & 0 \\
\hline Repeat variations & 0 \\
Total & 82 \\
\hline
\end{tabular}

ABCA3 gene analysis revealed one unreported homozygous mutation in the patient, but both parents were heterozygous (carrier) with normal lung function.

In this case, it is likely the missense mutation G202R (Gly202Arg substitution) in exon 6 caused dysfunction of the $A B C A 3$ protein, changing the polarity of amino acid chain, which surely must affect the functionality. This mutation has never been reported in either public data base of single nucleotide polymorphisms (http://www.ncbi. nlm.nih.gov/SNP/), and is located in the first extracellular loop, which intervenes in extracellular interactions that probably have severe effect on protein function.

To confirm the pathogenicity of the detected missense mutation, 70 unrelated healthy (without any clinical signs of lung disease) were searched for the mentioned change.

We used the sorting intolerant from tolerant (SIFT), polymorphism phenotyping 2 (Polyphen 2 ), predict SNP and mutation taster (www.mutationtaster.org) software to predict pathogenicity of detected mutation and its impact on $\mathrm{ABCA} 3$ function. All the mentioned programs predicted G202R as damaging. The clinical phenotype, genetic findings and computational analysis support its deleterious nature. However, our finding would expand the mutation database of the $\mathrm{ABCA}$ gene and might be useful for further individual screening, at least in Iran.

\section{Acknowledgments}

We gratefully acknowledge the Narges Genetic Laboratory staff and all members of the RDS patient's family for their cooperation. This study was supported in part by the grant no. 94/3/02/31918 from Shahid Chamran University.

\section{References}

1. Weichert N, Kaltenborn E, Hector A, Woischnik M, Schams A Holzinger A, et al. Some ABCA3 mutations elevate ER stress and initiate apoptosis of lung epithelial cells. Respir Res. 2011;12:4. doi:10.1186/1465-9921-12-4. [PubMed:21214890]

2. Piehler AP, Ozcurumez M, Kaminski WE. A-Subclass ATP-Binding Cassette Proteins in Brain Lipid Homeostasis and Neurodegeneration. Front Psychiatry. 2012;3:17. doi: 10.3389/fpsyt.2012.00017. [PubMed: 22403555]

3. van der Deen M, de Vries EG, Timens W, Scheper RJ, TimmerBosscha H, Postma DS. ATP-binding cassette (ABC) transporters in normal and pathological lung. Respir Res. 2005;6:59. doi: 10.1186/1465-9921-6-59. [PubMed:15967026]

4. Kim WS, Weickert CS, Garner B. Role of ATP-binding cassette transporters in brain lipid transport and neurological disease. J Neurochem. 2008;104(5):1145-66. doi: 10.1111/j.1471-4159.2007.05099.x. [PubMed: 17973979]

5. Panigrahy N, Poddutoor PK, Chirla DK. ATP-binding cassette transporter $\mathrm{A} 3$ ( $\mathrm{ABCA} 3)$ mutation in a late preterm with respiratory distress syndrome. Indian Pediatr. 2014;51(7):579-80. [PubMed: 25031143]

6. Klugbauer N, Hofmann F. Primary structure of a novel ABC transporter with a chromosomal localization on the band encoding the multidrug resistance-associated protein. FEBS Letters 1996;391(1):61-5. doi: 10.1016/0014-5793(96)00700-4. [PubMed 8706931]

7. Bullard JE, Nogee LM. Heterozygosity for ABCA3 mutations modifies the severity of lung disease associated with a surfactant protein C gene (SFTPC) mutation. Pediatr Res. 2007;62(2):176-9. doi: 10.1203/PDR.ob013e3180a72588. [PubMed:17597647]

8. Nagata K, Yamamoto A, Ban N, Tanaka AR, Matsuo M, Kioka N et al. Human ABCA3, a product of a responsible gene for abca3 for fatal surfactant deficiency in newborns, exhibits unique ATP hydrolysis activity and generates intracellular multilamellar vesicles. Biochem Biophys Res Commun. 2004;324(1):262-8. doi 10.1016/j.bbrc.2004.09.043. [PubMed:15465012]

9. Lyra PP, Diniz EM. The importance of surfactant on the development of neonatal pulmonary diseases. Clinics (Sao Paulo). 2007;62(2):181-90. [PubMed:17505704] 